\title{
THE FRENCH IN EXILE AND POST-WAR INTERNATIONAL RELIEF, c. $1941-1945$
}

\author{
LAURE HUMBERT* \\ University of Manchester
}

ABSTRACT. This article explores Free French responses to Allied planning for post-war international relief in Europe. A number of French experts in exile, often veterans of the League of Nations, advocated international co-operation with the nascent United Nations Relief and Rehabilitation Administration (UNRRA). For such figures, participating in the UNRRA could bring critical knowledge, political legitimacy, experience, and funds. They also hoped that this participation could bolster French prestige in the wake of the recent experience of defeat and foreign occupation. Their efforts had little impact on the early development of international relief, yet the contacts and exchanges between French and Allied planners resulted in a political imperative that gave a new impetus to the post-war restructuring of French relief abroad. Studying the complex inter-relationship between French foreign policy and humanitarian efforts during the Second World War can offer historians a framework through which to reconsider French attempts to reassert their power globally. Crucially, this article argues that the UNRRA was used by a number of French expert planners as a platform from which to pursue broader political aims, notably the reassertion of republican legitimacy and the re-establishment of national sovereignty.

Histories of the United Nations Relief and Rehabilitation Administration (UNRRA) focus overwhelmingly on the perspectives of the United States and Britain, the two main contributing countries. Written from the perspectives of British and American internationalists, such analyses have inevitably, and understandably, illuminated the unequal geopolitics of the internationalization of relief and confirmed a well-established narrative in the history of international power politics of a transition of power from Britain to the United States. Established in the West during the Cold War, this narrative is problematic, not least because it is partial. It has resulted in an incomplete picture of

Department of History, University of Manchester, Oxford Road, Manchester, MI39PL laure.humbert@ manchester.ac.uk

* The author would like to thank Martin Thomas, Charlotte Faucher, Jean-Marc Dreyfus, Craig Griffiths, James Connolly, and the anonymous readers of the Historical Journal for their instructive comments on earlier drafts of this article. I have given a version of this article at the Institute of Historical Research and Aberystwyth: thanks to all who attended for their helpful comments. 
this international organization and the medical and humanitarian discourses surrounding it. In recent years, a growing body of work has challenged this Anglo-American bias, aiming to 'de-centre' the history of the UNRRA and demonstrating that different visions of internationalism co-existed within the institution. ${ }^{1}$ Integrating the perspectives of Eastern and Central European countries into the analysis, Jessica Reinisch has highlighted how these states understood international aid differently. This methodological shift has unearthed important and under-studied parallels in the aftermath of the two world wars. Representatives of Eastern European states expected, for instance, the UNRRA to provide 'compensation' for past failures and serve as a mechanism for guaranteeing their security and containing Germany and the Soviet Union. ${ }^{2}$

There remains little reflection either on France's involvement in this organization or on the relationship between this involvement and the crises occurring in French metropolitan and colonial territories. The vast literature on France in the Second World War has similarly overlooked the encounters between French and Allied health and relief experts and between French bureaucrats and wartime international organizations. Meanwhile, new research on the international networks of the French resistance suggests that there is still a great deal that we need to understand about its attempts to restore France's international influence, in particular through means of soft power. 3 At the centre of these efforts is a fascinating paradox. No other European government in

${ }^{1}$ The literature on the UNRRA is vast. See for example George Woodbridge, UNRRA: the history of the United Nations Relief and Rehabilitation Administration (3 vols., New York, NY, 1950); Elizabeth Borgwardt, A new deal for the world: America's vision for human rights (Cambridge, MA, 2005); Andrew Williams, Liberalism and war: the victors and the vanquished (London, 2006); Susan Armstrong-Reid and David Murray, Armies of peace: Canada and the UNRRA years (Toronto, ON, 2008); Jessica Reinisch, 'Introduction: relief in the aftermath of war', Journal of Contemporary History, 43 (2008), pp. 371-404; Jessica Reinisch, “'Auntie UNRRA" at the crossroads', Past and Present, 8 (2013), pp. 70-97; Rana Mitter, 'Imperialism, transnationalism, and the reconstruction of post-war China: UNRRA in China, 1944-1971', Past and Present, 8 (2013), pp. 51-69; Ludovic Tournès, 'The Rockefeller Foundation and the transition from the League of Nations to the UN (1939-1946)', Journal of Modern European History, 12 (2014), pp. 323-41; Stephen Porter, 'Humanitarian diplomacy after World War II: the United Nations Relief and Rehabilitation Administration', in Robert Hutchings and Jeremi Suri, eds., Foreign policy breakthroughs: cases in successful diplomacy (Oxford, 2015), pp. 21-46.

${ }^{2}$ Jessica Reinisch, 'Internationalism in relief: the birth (and death) of UNRRA', Past and Present, 6 (2011), pp. $25^{8-89}$, at p. 279.

${ }^{3}$ Joseph Nye, Soft power: the means to success in world politics (New York, NY, 2004), p. x. The literature on the international networks of the French resistance is vast. See for example Emmanuelle Loyer, Paris à New York: intellectuels et artistes français en exil, 1940-1947 (Paris, 2005); Sylvain Cornil-Frerrot and Philippe Oulmont, eds., Les Français Libres et le monde: actes du colloque international au Musée de l'Armée, 22-23 novembre 2013 (Paris, 2015); Bruno Leroux, 'Comités de la France Libre dans le monde', in Jean-François Muracciole and Guillaume Piketty, eds., Encyclopédie de la Seconde Guerre mondiale (Paris, 2015), pp. 234-6; Charlotte Faucher and Laure Humbert, 'Introduction-beyond de Gaulle and beyond London: the French external resistance and its international networks', European Review of History (forthcoming, Apr. 2018). 
exile established a machinery of government comparable to that of the French Committee of National Liberation (FCNL) in Algiers. 4 Yet, the French Committee was never fully recognized as a government-in-exile by its Allies. 5 French officials were therefore forced to develop channels unfamiliar to classical diplomacy in their relations with foreign countries. It was outside of the traditional diplomatic circles that the first 'diplomatic' representatives of General de Gaulle were recruited in 1940, particularly amongst French academics and scientific experts. If recent scholarship has staked a claim for the study of the cultural diplomacy of the French Committee, historical insight into the Committee's international ambitions in the field of philanthropy, health, and humanitarianism remains lacking.

A richer history of French international activities can only emerge by integrating more fully the scholarship on wartime international organizations; a scholarship that has focused on the unequal power and influence of states within these organizations, but also recognized the opportunity that was opened up, even unintentionally, for representatives of smaller states and non-state actors within these organizations. ${ }^{6}$ Drawing on archival documents from the French Committee of National Liberation and Provisional Government (La Courneuve), the French Foreign Ministry (La Courneuve), the UN Archives (New York), the Foundation Jean Monnet (Lausanne), and private papers held at the French National Archives (Pierrefitte), this article examines the extent to which the UNRRA was used by French policy elites and experts as an international platform from which to pursue broader political aims, including the reassertion of republican legitimacy and re-establishment of national sovereignty. In doing so, it considers the varied character of the French resistance's strategies for regaining and asserting France's influence internationally after the defeat of 1940. For French planners, the UNRRA was much more than a humanitarian programme, encompassing issues of domestic reconstruction, imperial control, and prevention of any future resumption of German aggression. This article elucidates that three arguments underpinned French visions of the UNRRA: an economic one, the UNRRA being seen as a source of

4 Jean Louis Crémieux-Brilhac, 'La France Libre et l'état républicain', in Marc Olivier Baruch and Vincent Duclert, eds., Serviteurs de l'état: une histoire politique de l'administration française, $1875^{-1945}$ (Paris, 2000), pp. 539-49, at p. 546.

5 Jean-Baptiste Duroselle, L'abîme (Paris, 1982), p. 477.

6 Glenda Sluga and Patricia Clavin, 'Rethinking the history of internationalism', in Glenda Sluga and Patricia Clavin, eds., Internationalism: a twentieth-century history (Cambridge, 2016), pp. 3-14, at p. 9; Victor-Yves Ghebali, Organisation internationale et guerre mondiale: le cas de la Société des nations et de l'Organisation international du travail pendant la Seconde Guerre mondiale (Brussels, 2013); on the relations between the Vichy government and the League, the resistance, and nascent international organizations, see for example Victor-Yves Ghebali, La France en guerre et les organisations internationales, I939-1945 (Paris, 1969); Marie Claude Smouts, La France à l'ONU (Paris, 1979); Denis Mylonas, La Conférence des Ministres alliés de l'Education, Londres, I942-I945 (Brussels, 1976); Jean-Jacques Renoliet, L'UNESCO oubliée: la Société des nations et la cooperation intellectuelle, I919-1946 (Paris, 1999). 
supplies; a political one, the UNRRA allowing the FCNL without state status to envisage its place in the post-world order; and, finally, a security argument. From this perspective, international post-war relief was an essential prerequisite for the construction of a stable and peaceful post-war order.

Since Akira Iriye's seminal call to study 'cultural internationalism', research into the origins, character, and evolution of a host of international organizations, including the UNRRA, has proliferated.7 These studies have revealed that the UNRRA, like most international organizations, was the result of a mixture of political principles, self-interest, and compromises. ${ }^{8}$ The UNRRA programme, as it emerged in 1943 after the forty-four-nation conference in Atlantic City, was a complex combination of political calculation and an ideological commitment to a democratic peace, based on principles of economic and social rights. The UNRRA was the product of difficult diplomatic bargaining between the geopolitical and national interests of the 'Four Policemen': the United States, the United Kingdom, the Soviet Union, and China. The United States, which financed the great majority of the organization's programmes, was the driving force behind these negotiations. Both of the UNRRA's general directors (Herbert Lehman and his successor Fiorello H. La Guardia) were Americans. The UNRRA was also the cultural product of a renewed enthusiasm for international co-operation in the domain of health and humanitarianism and a part of broader humanist dreams to remake the world afresh in the wake of fascism. For many experts, among whom veterans of the League of Nations, the key to peace required economic stability as well as political security. And yet, there is little interrogation of the ways in which the international discourses around medical and humanitarian relief, and its institutional expression in the form of the UNRRA, were mobilized by the French to serve their national interests.

Acknowledging the French contribution to the UNRRA means recognizing the inequalities of power and influence within the organization, while appreciating its importance in the creation of a political sphere that gave voice to a broad array of actors, which were not represented in traditional diplomatic and state channels. In so doing, this article unearths fascinating parallels, along with a number of interesting contrasts, between French approaches to international aid and the post-war settlement after the two world wars. In 1943, French UNRRA delegates were influenced by their predecessors' efforts at attaining security through international law and the League. Yet, they were forced to confront the reality of France's intermediary status in the wake of the defeat of 1940. The question of how these French UNRRA delegates embraced internationalism

7 Akira Iriye, Cultural internationalism and world order (Baltimore, MD, 1970); Sunil Amrith, 'Internationalising health in the twentieth century', in Sluga and Clavin, eds., Internationalisms, pp. $245^{-64}$.

8 See n. 1. 
as the best way to restore France's influence and ensure peace and security has not received the attention it deserves.

While recent research has shed new light on French versions of internationalism in the aftermath of the First World War, more studies need to be done on French agents and visions of internationalism in the era of the Second World War, going beyond the crucial role that René Cassin played in the drafting of the Universal Declaration of Human Rights. 9 These French UNRRA experts came from different backgrounds and did not share a rigid ideological agenda or 'expert culture'. ${ }^{10}$ Instead, they formed a heterogeneous group, supporting liberal and democratic values, but divided in their assessment of what the new international order should amount to. Some accrued political power in the French National Committee and later the FCNL, including René Cassin as secretary of the Council for Defence of the Empire and then as minister for justice and education, and Jean Monnet as commissar for armaments and René Massigli as commissar for foreign affairs. Others had less political influence. Representing France in the food and agriculture conference in Hot Springs in May-June 1943 and later in the UNRRA Health Committee, André Mayer was, for instance, rarely able to make his advice heard by directly counselling the political decision-makers. Their encounters with European and Allied experts were not always progressive or co-operative in nature. While some French delegates advocated international co-operation, others were reluctant to share information about the political and sanitary situation in France. The UNRRA had been created to co-ordinate the purchase of food and raw materials, combat infectious diseases, assist displaced persons, and (some thought) start the process of economic rehabilitation. The field of health was where Franco-UNRRA co-operation became the most visible. From the beginning, the French National Committee urged Free French doctors not only to fulfil their medical mission but also to represent 'La France médicale' ('medical France') in international gatherings and through medical publications. ${ }^{11}$

This article is divided in five sections with an overarching chronological framework. This framework helps clarify the evolution of French policies towards international relief, which were at first intertwined with French reassertion of republican legitimacy, and national sovereignty, and later with the problem of the repatriation of French nationals. Following a brief examination

9 See for example Jessica Reinisch, 'Introduction: agents of internationalism', Contemporary European History, 25 (2016), pp. 195-205; Volker Prott, 'Tying up the loose ends of national self-determination: British, French and American experts in peace planning, 1917-1919', Historical Journal, 57 (2014), pp. 727-50; Peter Jackson, Beyond the balance of power: France and the politics of national security in the era of the First World War (Cambridge, 2014).

${ }^{10}$ Martin Kohlrausch, Katrin Steffen, and Stefan Wiederkehr, eds., Expert cultures in Central Eastern Europe: the internationalization of knowledge and the transformation of nation states since World War I (Osnasbrück, 2010); Davide Rodogno, Bernhard Struck, and Jakob Vogel, eds., Shaping the transnational sphere: experts, networks and issues from the I84os to the I930s (New York, NY, 2015).

${ }_{11}$ Guy Chauliac, Le service de santé de la France Libre (Paris, 1994), pp. $21-2$. 
of the changes that took place in how co-operation between inter-Allied or international organizations was conceived by French actors in exile in 1941-2, the article proceeds to an examination of French responses to the creation of the UNRRA in 1943. At the UNRRA's first Council, French political elites attempted to use the UNRRA as an international platform to advance broader political aims, including the re-establishment of national sovereignty and procurement of relief goods for liberated France. Yet, during this period, Allied relief policies presented a formidable challenge to French officials, who could not influence policies in the way they would have liked. This article then proceeds to outline French difficulties in developing a 'technical co-operation' with the UNRRA in 1944. Finally, I survey the reasons why French officials decided in 1945 to settle an agreement with the UNRRA, despite widespread disappointment about the UNRRA's early performance. These contacts and exchanges between French and Allied planners, I argue, albeit unsuccessful, revealed vast potential and point to a political imperative that gave a new impetus to the post-war restructuring of French relief abroad. Co-operating with the UNRRA was only a small aspect of French diplomats' work to restore France's international influence.

\section{I}

Planning for post-war relief began in the Allied capitals of London and Washington long before hostilities ceased in 1945. Memories of the catastrophic after-effects of the First World War, including the Spanish influenza, the Ukrainian famine, and the major typhus outbreak in Russia, lent urgency to the advocates of a massive international reconstruction programme for those countries devastated by war. These preoccupations informed the creation of the UNRRA in November 1943. The UNRRA's aim was to supply war-torn countries and displaced populations with the basic resources necessary to begin the process of rehabilitation, such as food provision and medical relief. The UNRRA distinguished itself in scope, budget, and organization from the League, operating through governments rather than as co-ordinator of relief operations independently conducted by private charities. It was hoped that the creation of this inter-governmental relief agency would help to prevent the inter-state competition and widespread inter-ethnic confrontation evident after 1918, notably during the famine in the Volga region. Integral to this new approach was the new, more interventionist and internationalist turn in American diplomacy. Convinced that American aims were best served within a multi-lateral relief organization, American policy elites and relief planners invited their British, Soviet, and Chinese counterparts to discuss the mandate and structure of this new international organization in 1942 , before submitting their draft to the forty-four nations in 1943 .

The period of the creation and early development of the UNRRA coincided with the establishment of the FCNL in Algiers. In its negotiations with the 
nascent UNRRA, as elsewhere on the international scene, France was forced to confront the reality of being eclipsed as a major world power after the German invasion of 1940 and its quick defeat. In stark contrast with the days of Pariscentred peace-making in 1919, in 1942-3 the key decisions concerning the UNRRA and the post-war settlement were taken by the United States, Great Britain, and the Soviet Union, often at the virtual exclusion of French representatives. Hervé Alphand, the former financial adviser of the French embassy in Washington and member of the French UNRRA delegation, spoke for many when he noted in December 1943 that 'France is weak; it is a negligible country.' ${ }^{12}$

By the 1940s, French diplomats and health experts had a long history of involvement in the 'international sanitary system' that emerged in the mid-nineteenth century, and developed into the Health Section of the League of Nations. ${ }^{3}$ For French planners in exile, re-establishing links with international organizations was an important element in the process of gaining political legitimacy and restoring France's image both in France and abroad. Following France's defeat, the French director of the Secretariat of the League of Nations, Joseph Avenol, resigned in July 1940, and in April 1941 the Vichy deputy premier Admiral Darlan withdrew France from the League. ${ }^{14}$ De Gaulle might have claimed 'We are France' but his Committee was neither recognized as such by its Allies nor by the majority of French citizens or exiles in 1940. For the League of Nations, for instance, the Vichy regime was considered the legal representative of the French people. This problem of sovereignty was key to French resistance politics both in metropolitan France and abroad. ${ }^{15}$ For many British and American planners, this French fixation on issues of sovereignty and independence was deeply wearisome.

In September 1941, on the same day that de Gaulle unveiled the political structure of the French National Committee to the public, René Cassin, representing Free France at the second inter-Allied conference at St James's Palace, proclaimed that France adhered to the principles of the Atlantic Charter. ${ }^{16}$ Adhering to the Atlantic Charter could help contradict rumours (particularly prevalent in British official circles) about de Gaulle's autocratic tendencies, at

12 Hervé Alphand, L'étonnement d'être: journal, 1939-1973 (Paris, 1977), p. 171.

13 See for example Mark Harrison, 'Disease, diplomacy and international commerce: the origins of international sanitary regulation in the nineteenth century', Journal of Global History, 2 (2006), pp. 197-217; Iris Borowy, Coming to terms with world health: the League of Nations Health Organisation, I92 I-I946 (Berlin, 2009).

14 Ghebali, Organisation internationale et guerre mondiale, p. 285.

15 See for example Sandrine Kott, 'Fighting the war or preparing for peace? The ILO during the Second World War', Journal of Modern European History, 12 (2014), pp. 359-76; Jaci Eisenberg, 'Laquelle était la vraie France? France and the ILO during the Second World War', in J. van Daele, M. R. García, G. Van Goethem, and M. van der Linden, eds., ILO histories (Bern, 2010), pp. 341-64.

${ }^{16}$ Jay Winter and Antoine Prost, René Cassin and human rights: from the Great War to the Universal Declaration (Cambridge, 2013), pp. 134-5. 
a time when he struggled to establish his pre-eminence over the different components of the French resistance. As much as the Atlantic Charter can be regarded as wartime rhetoric and an American 'public relations invention' to convince American isolationists to support the war effort, Free France's adherence to the Atlantic Charter (and later to UN rhetoric) can also be seen as an 'anti-Vichy' public statement.

De Gaulle was, however, much more circumspect about the Atlantic Charter, and the rhetoric of the nascent United Nations more broadly than René Cassin and other French internationalists. In January 1942, he rejected the (belated) American invitation to sign the UN declaration. Political calculations were at the forefront of his refusal to endorse the declaration. On 24 December 1941, French admiral Emile Muselier seized the islands of St Pierre et Miquelon, following a secret instruction from de Gaulle ordering him to seize the islands. The US State Department reacted disproportionally in its criticism, suspecting de Gaulle of seeking to undermine the foundations of American policy towards France. Americans blamed de Gaulle for placing the interests of the French Committee above Allied strategic necessities. Thus, in the wake of this fiasco, Roosevelt did not invite de Gaulle to sign the declaration of the United Nations in January 1942. ${ }^{17}$ However, upon British insistence, three days later the American State Department agreed to modify this, by admitting signatories not recognized as 'governments-in-exile'. The Free Danish authorities accepted this invitation, but de Gaulle refused it categorically. ${ }^{18}$

As Allied governments increasingly drew on universal principles to sustain their war efforts, expert groups were formed to consider how these principles were to be applied in the post-war world. On 2 December 1941, the French Committee created four commissions for the study of post-war problems. Hervé Alphand presided over the first commission on economic and financial matters. Alphand contributed notably to the discussions of the InterAllied Committee on Post-war Requirements, established in September $194^{1}$ by Churchill under the chairmanship of Sir Frederick Leith Ross. ${ }^{19}$ Leith Ross was eager to secure American aid and avoid the errors of the post-1918 reparation settlement. This Inter-Allied Committee soon became a clearinghouse for intelligence on the post-war needs of continental Europe. It gathered likely requirements for relief materials in the occupied countries, discussed spoliations and the legal robbery undertaken by the Nazis in occupied Europe, and made provisions regarding road transports, health, and displaced persons.

17 Martin Thomas, The French empire at war, I940-1945 (Manchester, 2007), pp. 134-9.

${ }_{18}$ Archives Nationales, Pierrefitte-sur-Seine (AN), papiers de Gaulle, 3/AG1/262, note de Dejean, 26 Sept. 1943; note de Massigli au Général de Gaulle, 2o Oct. 1943.

19 On the history of this Inter-Allied Committee, see Johannes-Dieter Steinert, 'British humanitarian assistance: wartime planning and postwar realities', Journal of Contemporary History, 43 (2008), pp. 421-35; Georges Bossuat, La France, l'aide américaine et la construction européenne, I944-1954 (Vincennes, 1997); Frances Lynch, France and the international economy: from Vichy to the Treaty of Rome (London, 2006), pp. 1 7-19. 
Participation in this Inter-Allied Committee enabled French experts to obtain precious Allied knowledge and fill some data gaps, at a time when they did not have access to the files of the French Ministry of Foreign Affairs. It was also a way to attract American support, at a time when the United States still maintained diplomatic relations with Vichy. ${ }^{20}$ Alphand hoped that this could bolster French prestige, by demonstrating that the French had a brand of ideas that was still worth exporting. ${ }^{21}$

Technical co-operation between French and Allied experts was important, but its influence over policy-making during this period should not be exaggerated: French planners were often excluded from more political discussions about wartime relief and refugee issues. In February 1943, René Massigli took over the Commissariat of Foreign Affairs, replacing Maurice Dejean, de Gaulle's former foreign affairs commissar. Under Massigli's direction, the Commissariat grew and preparation for peace, post-war relief, and the administration of Germany intensified. ${ }^{22}$ In May and June, Alphand participated with André Mayer and Christian Valensi, the future financial controller of the French mission in Washington, in the food and agriculture conference at Hot Springs. Yet, French representatives were not invited to the Anglo-American inter-governmental conference on refugee issues in mid-April 1943 in Bermuda. At the time, the French Committee was embroiled in a power struggle between General Henri Honoré Giraud and de Gaulle, both fighting for the right to lead France's overseas resistance to the Axis Powers. ${ }^{23}$ Both Giraud and de Gaulle were opposed to the creation of the 'North African refugee' rescue plan, mainly out of fears of political turmoil in Algiers. ${ }^{24}$ Expecting little co-operation and wary about selecting one man over the other, American authorities simply excluded them from the discussions about the refugee situation. De Gaulle, however, denounced these Anglo-American discussions as an infringement upon the French right to decide the future of French territories.

Organized at a distance from the world's press, this conference did little for European refugees, including persecuted Jewish refugees, apart from reviving the Intergovernmental Committee on Refugees (IGCR), created after the

${ }^{20}$ Guillaume Piketty, 'Les voies douloureuses de la reconquête: les négociations militaires et diplomatiques de la France Libre avec le géant américain en devenir, 1942-1943', in CornilFrerrot and Oulmont, eds., Les Français Libres et le monde, pp. $5^{1-64}$.

21 Alphand, L'étonnement d'être, p. 124.

${ }^{22}$ Jean-Baptiste Duroselle, 'Une création ex nihilo: le ministère des Affaires étrangères du Général de Gaulle (1940-1942)', Relations Internationales, 31 (1982), pp. 313-32; Raphaële Ulrich-Pier, 'Rebatir un réseau diplomatique: les délégués de la France Libre à l'étranger', in Cornil-Frerrot and Oulmont, eds., Les Français Libres et le monde, pp. 109-23.

$23 \mathrm{AN}, 457 / \mathrm{AP} / 1$, papiers Georges Bidault, 'Le $1{ }^{\mathrm{er}}$ Mars 1943 La France adhère à la charte de l'Atlantique'.

${ }^{24}$ Timothy P. Maga, America, France and the European refugee problem, I933-1947 (New York, NY, $198_{5}$ ), p. 247 . 
earlier Evian conference in 1938 at the initiative of Roosevelt. ${ }^{25}$ In 1943, the persecution of European and French Jews was neither the main priority of the French Committee nor those of its Anglo-American Allies. De Gaulle condemned Vichy anti-Semitic policies, but remained attached to an 'imperative of discretion', dictated both by some anti-Semitic attitudes among Free French members and by British policy of not singling out Jews as victims of Nazi persecution. ${ }^{26}$ Concerned about the effectiveness of German propaganda, which presented his Committee as being 'controlled by the Jews', de Gaulle sought to avoid drawing attention to an entirely new category of people in need of relief: Jewish survivors.

\section{I}

In June 1943, only two months after the Bermuda conference, Free French policy elites received the Four-Powers UNRRA draft proposal. ${ }^{27}$ This proposal was the result of a long negotiation process between the Allies, initiated by the Soviet Union in January 1942. It was towards the beginning of 1942 that the Soviets began to envision the creation of an international relief organization as an instrument for reshaping the international order. In response, the British submitted their own distinct proposal to the Americans within a month. Recent studies show how preparation for the UNRRA functioned as a medium for wartime co-operation among the British, American, and Soviet states with different visions and objectives, and also how it became the battleground of an intense political and ideological struggle about the shape of the new international order. ${ }^{28}$ The UNRRA's aim was to provide living essentials to millions of civilians involuntarily moved from their homes during the war. Behind this consensus, Allied planners disagreed over which states were to administer the relief project, for how long, and which populations should benefit from it.

Two main issues emerged during the six meetings held between American, British, Soviet, and Chinese representatives in Washington from January to May 1943: first, the organization's right to operate in a territory without the

${ }^{25}$ A representative of the IGCR was nevertheless accredited in Algiers. Archives de la Fondation Jean Monnet pour l'Europe, Lausanne (AFJME), AME 45/3/2, lettre de Georges Coulon à Monsieur Jean Monnet, 3o Oct. 1943; MAE, Alger, Comité Français de Libération Nationale-Gouvernement Provisoire de la République Française (CFLN-GPRF), 694, Dejean à Massigli, Londres, 14 Dec. 1943. Also see Dzovinar Kévonian, 'Diplomates et juristes face à la question de la protection des réfugiés en France du Bureau chargé des intérêts des apatrides de Vichy à la mise en place de l'OFPRA', in A. Angoustures, D. Kévonian, and C. Mouradian, eds., Refugiés et apatrides: administrer l'asile en France, 1920-1960 (Paris, 2017), pp. $95^{-11} 1$.

${ }_{26}$ Renée Poznanski, Propagandes et persecutions: la résistance et le 'problème juif', I940-I944 (Paris, 20o8), pp. 139, 143; Jean-Marc Dreyfus, L'impossible reparation: déportés, biens spoliés, or nazi, comptes bloqués, criminels de guerre (Paris, 2015), p. 33.

27 AFJME, AME 45/1/37, agreement for UNRRA, draft, 15 May 1943; AME 45/1/42, Dean Acheson to Dr Wei Tao-Ming, Chinese ambassador, 9 June 1943.

${ }_{28}$ See n. 1 . 
consent of local authorities and, second, the size and composition of the UNRRA Central Committee. ${ }^{29}$ The first problem stemmed from Soviet representatives' reluctance to accept encroachments on national sovereignty in their territories in exchange for international aid. The second issue derived from American's insistence on the creation of a four-power Central Committee. The British advocated instead the formation of a seven-member Committee including a Commonwealth country, another European and a Latin American state. $3^{\circ}$ The British combined economic and political arguments in the defence of a seven-power set up, insisting that this would appease Canada and the governments-in-exile that had important supplies to offer. Members of the League's Princeton Mission also called for a revision of the American proposal on the grounds that it was profoundly anti-democratic. ${ }^{31}$ Yet, these propositions ran up against the same obstacles as so many other propositions for reforming international organizations ever since: the refusal of the Great Powers, and here the United States, to surrender sovereignty for the benefit of collective action.

The evidence suggests that Jean Monnet had access to some of the minutes of the meetings, although the French Committee was not officially invited to the negotiating table. $3^{2}$ One aspect of these debates was of particular interest for Monnet: the composition of the Central Committee. At Britain's insistence, France's prospects for membership on the Central Committee was discussed in the fifth meeting in April 1943. This discussion happened just as the conflict between de Gaulle and Giraud entered its most difficult period, when Franco-American relations were marred by American anger at de Gaulle's tenacity in pressing for a unified committee and suspicion of BritishGaullist collusion. In this context, the Americans were not persuaded by the British argument that it served the Allied interest to back Free France's participation in the UNRRA Central Committee. As a result, the French Committee was invited to sign the UNRRA's Agreement, as all European countries, but was not offered a seat on the Central Committee.

The final UNRRA proposal met with a relatively positive response from Allied governments. By 21 July 1943, the governments of Greece, Yugoslavia, Canada,

29 C. W. Sharpe 'The origins of the United Nations Relief and Rehabilitation Administration, 1939-1943' (D.Phil. thesis, Pennsylvania, 2012), pp. 537-653.

$3^{\circ}$ AFJME, AME 45/1/16, memorandum of discussion in Mr Acheson's office, 11 Jan. 1943.

$3^{1}$ Patricia Clavin, Securing the world economy: the reinvention of the League of Nations, I920-I946 (Oxford, 2013), p. 298.

$3^{2}$ AFJME, AME 45/1/10 and 11, 'Memorandum' with Mr Liu Chieh's compliments (undated); AME 45/1/16, memorandum of discussion in Mr Acheson's office, Department of State, 11 Jan. 1943; AME/45/1/22, memorandum of discussion in Mr Acheson's office, Department of State, 17 Feb. 1943; AME/45/1/25, memorandum of discussion in $\mathrm{Mr}$ Acheson's office, Department of State, 27 Feb. 1943; AME/45/1/27, memorandum of discussion in Mr Acheson's office, Department of State, 24 Mar. 1943; AME/45/1/28, UNRRA minutes of discussion, 24 Mar. 1943. According to Sharpe, the Chinese ambassador to the United States Wei Tao-Ming leaked the documents: Sharpe, 'The origins of UNRRA', p. 540. 
Brazil, Mexico, Bolivia, Costa-Rica, and Guatemala had accepted the proposal.33 Yet, most European governments-in-exile disapproved of the organization's undemocratic structure and feared the power of the director general.34 The European governments shared similar concerns (albeit to a greater or lesser degree) about Great Power dominance. The Czechs required an expansion of the Committee to include another European representative.35 The Belgians insisted on countries' rights to obtain payments in kind from enemy states corresponding to the spoliation their economic systems had suffered. $3^{6}$ The Poles called for more power for the regional committees and an expansion of the Central Committee. 37 In comparison, the official French response was, although tardy, relatively favourable..$^{8}$

France's response to the UNRRA proposal was elaborated in the summer of 1943 in a highly fraught political atmosphere. Two developments were particularly important for the future evolution of French UNRRA policy. The first was that the creation of the FCNL in June ended what Jean-Baptiste Duroselle has called the 'era of the Three Frances', divided between the Vichy government in metropolitan France, the Gaullist Committee in London, and the Giraudists in Algiers.39 No longer paralysed by the conflict between Giraud and de Gaulle, the FCNL was tasked with creating a 'resistant' state, whose capital was in Algiers. The second was the appointment of Jean Monnet as commissar of supplies and armaments, who was critical in pushing for the acceptance of the UNRRA proposal.

The official French position on the UNRRA was negotiated in the face of some important opposition from General Giraud, who endorsed the views of other European governments and invoked the need to oppose the powers of the director general. $4^{\circ}$ Too undemocratic for Giraud, the UNRRA proposal

33 AFJME, AME 45/1/56, memorandum of discussion in Mr Acheson's office, Department of State, 21 July 1943; letter from Alberto Echandi to D. Fay Allen, 16 July 1943.

34 AFJME, AME 45/1/46, lettre de A. Loudon à Cordell Hull, 28 June 1943; MAE, Alger, CFLN-GPRF, 689, traduction de la note que le gouvernement norvégien a chargé son ambassadeur à Washington de remettre au secrétaire d'état au affaires étrangères, 17 July 1943. Also see Sharpe 'The origins of the UNRRA', pp. 692-734.

35 MAE, Alger, CFLN-GPRF, 689, copy of the letter of the Czechoslovak government, 10 Aug. 1943 .

$3^{6}$ MAE, Alger, CFLN-GPRF, 689, copie de la lettre du MAE et du Commerce Extérieur de Belgique à l'ambassadeur des États-Unis, 19 July 1943.

37 MAE, Alger, CFLN-GPRF, 689, copy of the Polish letter, 24 July 1943.

$3^{8}$ MAE, Alger, CFLN-GPRF, 689, télégramme d'Alphand à Monnet, no. 614, 11 Aug. 1943; Oskar Halecki, 'East Central Europe in postwar organization', Annals of the American Academy of Political and Social Science, 228 (1943), pp. 52-9.

39 Duroselle, L'abîme, pp. 413-46; Martin Thomas, 'The discarded leader: General Henri Giraud and the Foundation of the French Committee of National Liberation', French History, 10 (1996), pp. 86-111, at p. 109 .

$4^{\circ} \mathrm{AN}$, papiers de Gaulle, 3/AG1/262, lettre du cabinet civil du Général Giraud à Monsieur le commissaire aux affaires étrangères, a/s du projet d'accord relatif à l'administration des Nations Unies pour l'assistance et la reconstruction; MAE, Alger, CFLN-GPRF, 689, note sur l'organisation du relief, 7 July 1943 . 
also appeared contradictory to the restitution plans developed by French experts who had worked in the Inter-Allied Committee for the Study of Armistice. The jurist André Gros posited that the UNRRA proposal contradicted French restitution plans, as it implied that France might have to pay for essential goods instead of Germany. ${ }^{4}$ This was not the perspective of Monnet and Alphand, for whom it was imperative rapidly to bring the relief organization into being irrespective of France's position within it and of the reparation issue. Both were convinced that France's reconstruction and European integration would not be possible without American aid..$^{2}$

Monnet's position reflected a longer-term continuity in the French approach to the political dimensions of economic co-operation.43 Monnet sought to promote European regionalism through the nascent UN system. $44 \mathrm{He}$ argued that France should be the inspiration behind the creation of a Western Europe. 45 This desire to create a 'new economic order' based both on containing German power and encouraging mult-ilateral co-operation was inspired in part by his work with the minister of commerce in the aftermath of the First World War. There were in fact clear continuities in conceptions of economic security between Monnet's 1943 plan and the programme presented in 1918 by the minister of commerce Etienne Clémentel that aimed to involve Germany in a multi-lateral system that would restrain its offensive economic policies. ${ }^{6}$ In 1943, Monnet was determined to avoid the errors of the post-1918 settlement. At thirty years old, he had been appointed assistant secretarygeneral of the League, where he worked from 1919 to 1922 and witnessed international conflicts resulting from the Paris Peace order. Monnet was worried that the British and Americans would leave occupied countries soon after the conflict, as they did (in part) after the First World War. For Monnet, out of the four main Allies, France was the only truly 'European power'. It was essential that it restore a democratic order in Europe, including Germany. But before this could be attempted, it had to make sure that 'chaos [did] not overtake Europe as a result of liberation'.47 In an exposé dated 28 July 1943, Monnet

$4^{1}$ Claude Lorentz, La France et les resistitutions allemandes au lendemain de la Seconde Guerre mondiale (Paris, 1998), p. 15.

$4^{2}$ Pierre Gerbet, 'Jean Monnet - Charles de Gaulle: deux conceptions de la construction européenne', in Gérard Bossuat and Andreas Wilkens, eds., Jean Monnet, l'Europe et les chemins de la paix (Paris, 1999), pp. 411-34.

43 Jackson, Beyond the balance of power, p. 178.

44 Frederic Fransen, The supranational politics of Jean Monnet: ideas and origins of the European Community (Westport, CT, 2001), p. 80.

45 François Duchêne, Jean Monnet: the first statesman of interdependence (New York, NY, 1994), p. 127; André Kaspi, La mission de Jean Monnet à Alger, mars-octobre I943 (Paris, 1971), p. 217.

$4^{6}$ Guy Rousseau, 'Etienne Clémentel, un inspirateur méconnu de Jean Monnet', Guerres mondiales et conflits contemporains, 186 (1997), pp. 3-15; Jackson, Beyond the balance of power, pp. $254,5^{1} 5$.

47 Marie-Renée Mouton, La Société des Nations et les intérêts de la France, I920-I924 (Berlin, 1995); Antoine Fleury, 'Jean Monnet au Secrétariat des Nations', in Bossuat and Wilkens, eds., Jean Monnet, pp. 31-41; Lubor Jilek, 'Rôle de Jean Monnet dans les règlements 
introduced a difference between 'immediate relief' (short-term emergency aid) and 'rehabilitation' (understood as longer-term reconstruction). $4^{8}$ French interest in the period of 'immediate relief' was that France should distribute UNRRA supplies in its territories.49 Obtaining this aid could help prevent chaos in France and limit the audience of the Communist Party, whose influence grew in the second half of 1943, after the Allies landed in Sicily in July. $5^{\circ}$ Monnet's long-term aim remained to request a seat on the Central Committee, once the initial stage of relief had ended.

The FCNL approved Monnet's report on relief and rehabilitation on 5 August $1943.5^{1}$ Given the anti-American atmosphere that existed in Algiers, this decision was, in some ways, surprising. At the centre of the decision was a fascinating paradox: eager to obtain a seat on the Central Committee and to present France as the 'natural representative' of other European nations, French officials were aware that they were in a weak political position. They also wanted to encourage the United States to act multi-laterally and avoid another American domestic debate, as had happened with the League. $5^{2}$ British officials had indeed advised the French to be prudent with their demands, highlighting the risk of angering the American Congress, the main source of the proposed agency's resources, and reawakening the demands of other countries, including Canada, Brazil, Argentina, and Poland. France had two important assets: it possessed an important fleet and was in a key geographical position for transporting goods to Central Europe. Hugh Dalton, the British minister of economic warfare, advised French authorities to wait until France had an elected government and was not only 'recipient' but also 'provider' of relief to ask for a seat on the Central Committee.53 Like the French, the British feared American economic imperialism. They dreaded that the US

d'Autriche et de Haute-Silésie', in Bossuat and Wilkens, eds., Jean Monnet, pp. 43-61; Alessandro Isoni, 'Jean Monnet, the UN administrative system and the creation of the ECSC high authority', in Francesco Petrini, ed., Networks of global governance: international organisations and European integration in an historical perspective (Cambridge, 2014), pp. 61-75; Wolf D. Gruner, 'La place de l'Allemagne dans l'Europe d'après-guerre selon Jean Monnet $\left(194^{0}-195^{2}\right)$ ', in Bossuat and Wilkens, eds., Jean Monnet, pp. $112-4^{6}$, at p. 126.

$4^{8}$ MAE, Alger, CFLN-GPRF, papiers Alphand, 1536 , organisation du 'secours immédiat' (relief) et de la 'Reconstruction économique' (Rehabilitation) à prévoir pour les territoires occupés, 28 July 1943 , p. 9.

49 Ibid.

$5^{\circ}$ Philippe Mioche, Le plan Monnet: genèse et élaboration, I94I-I947 (Paris, 1987), p. 75 .

$5^{1}$ AFJME, AME 35/3/4, Secretariat du Comité, no. 26, resumé des decisions prises au cours de la séance du 5 août 1943 .

$5^{2}$ MAE, Alger, CFLN-GPRF, 689, lettre de Pierre Viénot à René Massigli, Londres, 1 juillet 1943; conversation de M. Viénot avec M. Dalton a/s du relief, 3 July 1943; note confidentielle de R. Marjolin, la participation de la France à l'organisation du 'relief', 17 juin 1943; AN, 457/ $\mathrm{AP} / 1$, papiers Georges Bidault, note pour le Général de Gaulle, 8 Oct. 1943.

53 MAE, Alger, CFLN-GPRF, 689, conversation de M. Viénot avec M. Dalton a/s du relief, 3 July 1943 . 
would use aid as leverage to crack the preferential trading system of their empire, yet both were highly dependent on American supplies and money.

In its response to the UNRRA draft, the FCNL did not suggest any change to the administration's structure; it only insisted that a national organization should distribute UNRRA goods, and requested positions within several UNRRA regional or technical committees (the European, the Far East, and the Supply Committees). The French, however, also voiced their long-term aspiration: 'It appears inconceivable that France should not, when the time comes, resume its place by the side of China, the United States of America, Great Britain, and the U.S.S.R. on a footing of equality, in an enlarged central committee, as well as in the Councils of the United Nations.' 54 In the late summer of 1943, the Allies were slowly moving towards recognizing the authority of the FCNL. On 26 August 1943, the American government issued a statement partly recognizing the authority of the FCNL as the organization administrating France's overseas territories. Meanwhile, in Algiers, the FCNL established its relationship with the National Resistance Committee set up by Jean Moulin in metropolitan France, before his death in July 1943.

These developments remained in their early stages in 1943. The second half of that year saw neither the restoration of France to its former international status nor the full recognition of the FCNL. In the autumn, the FCNL, embroiled in a bitter imperial confrontation with Britain over Lebanese independence, was still striving to be recognized by its Allies as the undisputed government-in-waiting best placed to administer France. In this context, no changes were envisaged to the official French approach to the UNRRA, when France was presented with a new UNRRA proposal in September 1943.55 French approval of the UNRRA's new proposal followed the signature of the so-called 'modus vivendi' with the Americans on 25 September 1943, enabling lend-lease for North Africa and French colonies. By then, the FCNL was deeply concerned by the provision of food supplies for liberated France. $5^{6}$

In November 1943, Monnet was sent to Washington, with three different missions; finding supplies for France's immediate needs, preparing a programme of emergency reconstruction, and making plans for France's longer-term economic recovery. As early as August 1940, de Gaulle had voiced his serious concern about food provisions in France, resulting from German requisitions

54 MAE, Alger, CFLN-GPRF, papiers Alphand, 1536 , réponse du CFLN à la note du gouvernement des États-Unis d'Amérique, 12 Aug. 1943.

55 AFJME, AME 45/1/65, memorandum of discussion in Mr Acheson's office, Department of State, 19 Aug. 1943; MAE, Alger, CFLN-GPRF, papiers Alphand, 1536 , étude des différences existant entre le projet du 15 mai et celui du 20 septembre, Alger, 11 Oct. 1943.

$5^{6}$ AFJME, AME 35/3/22, résumé des decisions prises au cours de la séance du 14 octobre 1943; MAE, Alger, CFLN-GPRF, 693, lettre de l'ambassadeur de France à Monnet, 18 Oct. 1943 . 
and the British blockade. 57 The situation became even more worrying after the occupation of North Africa in November 1942, with Free French authorities fearing that widespread malnutrition would facilitate the spread of infectious diseases at the Liberation. Aware that the Vichy regime was losing the 'battle for food' in metropolitan France, Monnet's team had to secure aid for a liberated France, including food, clothes, and barracks for emergency housing. ${ }^{8}$ In the aftermath of the First World War, as deputy secretary of the League, Monnet had followed the League's work on the Russian famine. 59 Alongside his technical negotiations with the State Department and his work on the UNRRA's first Council, Monnet intended to draw American public attention to the dire food situation in metropolitan France. Robert Marjolin was entrusted with the mission of building contacts with American philanthropic organizations. He regularly dined with 'old women', profoundly Francophile, but 'whose means - as wealthy as they were - did not quite match the dimensions of the post-war problem'.6o Obtaining goods was all the more necessary since the Consultative Assembly in Algiers was hostile to the 'Anglo-Saxon' powers. The North African experience of 1943 had indeed revealed the difficulties of delivering aid on the ground. ${ }^{61}$

Supporters of Free France in Algiers thus judged the UNRRA against a basic criterion: its capacity to deliver essential supplies without undermining France's national sovereignty. ${ }^{62}$ At the UNRRA's first Council in Atlantic City, Monnet was surprised by the state of confusion among Americans and the tensions between the State and War Departments. ${ }^{6} 3$ He nevertheless enjoyed a close relationship with Dean Acheson, under-secretary of state and the UNRRA chairman. During the Council, Dean Acheson and Monnet often took early morning walks and dined together. ${ }^{6}$ Both agreed on the 'necessity of co-ordinating

57 MAE, Alger, CFLN-GPRF, 696, note pour le CFLN sur le ravitaillement des enfants du territoire métropolitain, Alger, le 17 Novembre 1943; James Dougherty, The politics of wartime aid: American economic assistance to France and French northwest Africa, 1940-1946 (London, 1978), pp. $4-5$.

$5^{8}$ See for example Jean Pierre Le Crom, 'Lutter contre la faim: le rôle du Secours National', in Isabelle von Bueltzingsloewen, ed., Morts d'inanition: famine et exclusions en France sous l'occupation (Rennes, 2005), pp. 249-62; Fabrice Grenard, 'Les implications politiques du ravitaillement en France sous l'occupation', Vingtième siècle, 94 (2007), pp. 199-215; AFJME, AME 45/ $1 / 76$, télégramme no. 26 pour M. Monnet, 29 Dec. 1943.

59 Archives of the League of Nations, R.1752/47/2135o, Norwegian government proposal concerning a Commission of Enquiry into the Russian Famine, note on conversation between Monsieur Monnet, Professor Attolico, and Mr Baker, 6 June 1922.

6o Robert Marjolin, Le travail d'une vie: mémoires, I9II-I986 (Paris, 1986), p. 120.

61 Letter from Massigli to Monnet, 3o Oct. 1943, quoted in Eric Roussel, Jean Monnet (Paris, 1996), p. 4 .

62 AFJME, AME 35/4/9, lettre de Massigli à Monnet, 25 Nov. 1943 .

63 AFJME, AME 45/3/7, Monnet à René Mayer, nos. 2709 à 2718, 7 Nov. 1943; AFJME, AME 45/3/40, Monnet à Mayer et Massigli, 'Question du débarquement', 24 Nov. 1943.

64 Douglas Brinkley, 'Dean Acheson and Jean Monnet: on the path to Atlantic partnership', in Clifford P. Hackett, ed., Monnet and the Americans: the father of a united Europe and his US 
civilian and military plans' for the initial phase of the Liberation. ${ }^{65}$ Despite Monnet's skills as a negotiator, however, as well as his friendship with Dean Acheson and his connections in the US State Department, he and his team did not influence post-war relief in the way they would have liked. Monnet chaired the Committee for Finance and Supplies, in which essential questions of post-war procurement were discussed and the informal committee for the recommendation of the director general's salary. ${ }^{66}$ His work in these two committees notwithstanding, the resolution passed at the UNRRA's first Council reflected the dominance of the two principal supplier nations, the USA and Britain.

On 1 December 1943, Jean Monnet publicly thanked Dean Acheson for the organization of a highly successful international conference: 'I have seen many international conferences in the course of many years. Never have I seen one guided with such skill, exceptional ability, and such charm. ${ }^{6}{ }_{7}$ In his telegrams to Algiers, Jean Monnet was far more circumspect about the results of this first conference. Although reassured by his understanding that the American authorities would rely on French civil authorities for the administration of France's liberated territories, he recommended his French counterparts not to wait for the 'setting-up of UNRRA' to prepare post-war relief. ${ }^{68}$ After his experience in North Africa and later in Atlantic City, he questioned the ability of the UNRRA to provide an efficient and quick response to France's humanitarian problems. For Monnet, the discussions about post-war relief and procurement had been highly politicized, and British, American, and Soviet relief policies had presented a formidable challenge to French policy elites. ${ }^{69}$

In spite of the extensive war damage in their country, French representatives insisted that France should not be designated a simple recipient nation and that a French administration should distribute relief provision in France. $7^{\circ}$

supporters (Washington, WA, 1995), pp. 71-101, at p. 79; Jean Monnet, Mémoires (Paris, 2014), pp. 301-21.

65 AFJME, AME 45/3/15, Monnet à René Mayer, 12 Nov. 1943; AFJME, AME 45/3/43, Monnet à Mayer, no. 2868, 25 Nov. 1943 .

${ }^{66}$ AFJME, AME 45/4/6, Dean Acheson to Jean Monnet, 21 Nov. 1943; AME 45/4/7, letter of M. Monnet, chairman, Dr Tsiang (China), Mr Kerstens (Netherlands), and Mr Sergeev (USSR), to Dean Acheson, 22 Nov. 1943.

${ }^{67}$ Verbatim minutes of the final plenary meeting 1 Dec. 1943, First session of the Council of the United Nations Relief and Rehabilitation Administration, Atlantic City, New Jersey, November IoDecember I, 1943 (US Government printing, 1944), p. 200.

68 AFJME, AME 45/3/9, télégramme de Monnet à Diplo-France Alger, no. 2738, 10 Nov. 1943; MAE, Alger, CFLN-GPRF, 69o, note sur les derniers télégrammes reçus de M. Jean Monnet, 3o Nov. 1943; AFJME, AME 35/2/1 7, René Mayer, note sur l'état des négociations menées par M. Monnet à Washington et à Atlantic City, Alger, 22 Nov. 1943.

69 MAE, Alger, CFLN-GPRF, 69o, télégramme secret de Washington, no. 2942, sent on 4 décembre 1943 .

$7^{\circ} \mathrm{AN}, \mathrm{F} / 9 / 3305$, note établie par les affaires étrangères sur les resolutions du premier conseil de l'UNRRA, Jan. 1944 . 
Consequently, the FCNL agreed to fund 4 per cent of the UNRRA's administrative expenses, a figure which matched that of India, but fell short in comparison with the American and British contributions. ${ }^{71}$ For all that, Monnet was not able to sign the UNRRA's Agreement in French, a key symbolic demand of French representatives. French authorities were particularly prickly about the 'eradication' of French in favour of English in international conferences. On 10 November 1943, he informed French planners in Algiers that Dean Acheson was not prepared to support French demands, essentially out of fear of angering South American representatives. ${ }^{72}$ The question of the French language in later discussions proved equally disappointing. American delegates refused to accept French as an 'official language', but conceded that French could be used during the Council discussion and in written agreements, an option that the Soviet delegates refused.73 French (and British) hopes that the UNRRA could have a longer-term remit were also shattered: the organization was designed on a purely temporary basis, responsible only for short-term relief. Finally, Monnet was frustrated by what he viewed as a lack of adequate French representation on the all-important Administration Boards. For example, France did not obtain the directorship of the European Committee, which was granted instead to Britain's Leith Ross.

In late 1943 and the early months of 1944, Monnet's strategy was to restore France's economic sovereignty and develop Franco-UNRRA co-operation in the 'technical' domains of health and repatriation. ${ }^{74} \mathrm{His}$ over-riding aim was to ensure that France was not classified as a 'receiving' country and to ensure that it 'remained entirely free from the control of an international body such as the UNRRA'.75 During this period, French UNRRA delegates grew both in confidence and influence, but still had little scope to shape the organization's early development. According to Monnet, the British wanted to bring to London (under their supervision) all the organizations that would play a role in the preparation of peace and the organization of post-war Europe. The Soviets were 'friendly, but notably distant' regarding the French. ${ }^{6}$ Consequently, French delegates favoured their continental European 'Allies',

71 See n. 77 .

72 AFJME, AME 45/1/69, Monnet à Meyer, pour les presidents et les membres du CFLN, 10 Nov. 1943; AFJME, AME 45/3/1, télégramme de Hoppenot, nos. 2549-51, 21 Oct. 1943.

73 AFJME, AME 45/3/55, télégramme no. 3oo6, Monnet à Mayer [signé Hoppenot], 14 Dec. 1943; MAE, Alger, CFLN-GPRF, 693, affaires étrangères à l'attention de Monnet et Alphand, 6 Nov. 1943 .

74 AFJME, AME 45/4/16, 'Décisions à prendre et tâches à executer', conférences dans le bureau de Monnet, 8-9 Dec. 1943; MAE, papiers Massigli, PAAP-2 1 7, vol. 42, note du commissaire aux affaires étrangères, conversation avec M. Van Zeeland, 2 Mar. 1944.

$75 \mathrm{AN}, \mathrm{F} / 9 / 3116$, Monnet à Mayer pour le Président Massigli et les membres du Comité, 19 Feb. 1944 .

$7^{6}$ AFJME, AME 45/3/48, Monnet à Mayer, no. 23, 14 Dec. 1943; MAE, Alger, CFLN-GPRF, 689, télégramme Alphand à Monnet et Massigli, 15 Aug. 1943 . 
using the conference in Atlantic City to develop their relations with Belgian, Luxemburgish, and Dutch authorities. 77

\section{I I}

Following the Council in Atlantic City, the former financial commissar Pierre Mendès France and Jean Monnet attempted to draw up a coherent FrenchUNRRA strategy and bring in French personnel into the administration. ${ }^{8}$ In May 1944, during the main debate about French foreign policy at the Consultative Assembly, the commissar for foreign affairs Massigli recognized the importance of France's participation in the UNRRA. 79 Yet, communication and co-operation between Algiers, London, and Washington proved problematic. The lack of available French experts and medical doctors with work experience in international organizations was also a significant obstacle. ${ }^{80}$ Monnet was, for instance, asked to suggest a name to direct the UNRRA's mission in Yugoslavia, yet was unable to find 'a good colonial administrator' ${ }^{81}$ In addition to the question of skills and competence, ideological problems existed. Within the Foreign Affairs Commissariat, many 'first hour resisters' were hostile to the arrival of personnel who had 'compromised' themselves with the Vichy regime.

At the level of the UNRRA technical committees working relationships did develop. For example, in the United States, the work of Professor André Mayer on the Standing Technical Committee on Health was highly acclaimed. ${ }^{82}$ Mayer, a veteran of the Health Section of the League, was a strong proponent of technical and scientific co-operation with the UNRRA, believing that the AngloAmericans could bring precious knowledge and experience. In his letters to his son Jean Mayer, he deplored the obsessive insistence on independence of the Algiers Committee when France faced the danger of tuberculosis and shortage of drugs. In the late 1930 , he had witnessed the shift in the medical understanding of 'hunger', from a quantitative lack of food to a biomedical view of 'malnutrition' linked to notions of quality of diet and health. Yet, in wartime

77 MAE, Alger, CFLN-GPRF, 69o, traduction d'un télégramme chiffré, 14 Decembre 1943; Pierre Guillen, 'La France Libre et le projet de fédération ouest européenne 1943-1944', in M. Dumoulin, ed., Plans des temps de guerre pour l'Europe d'après-guerre 1940-1947 (Brussels, 1995), pp. ${ }^{153}-73$.

${ }_{78}$ AFJME, AME 45/4/46, Monnet à Meyer pour le président et les membres du Comité, nos. 2411-15, 27 Apr. 1944; MAE, Alger, CFLN-GPRF, 692, commissaire des finances à monsieur l'ambassadeur de France, 27 Apr. 1944.

$79 \mathrm{MAE}$, papiers Massigli, 42, débats de l’Assemblée consultative provisoire, séance du vendredi 12 Mai 1944 .

8o MAE, Alger, 692, ambassade de France au Maroc à commissaire aux affaires sociales, 20 May 1944; AN, F/9/31 1 16, lettre secrète du commissaire aux PDR à monsieur le président de l'entr'aide française, 1 Apr. 1944 [signed Frenay].

${ }^{81}$ AFJME, AME 45/4/46, Jean Monnet à René Meyer pour le président et membres du Comité, 27 Apr. 1944.

${ }^{82}$ UNA, UNRRA, ERO files, S-O523-0012, bulletin, UNRRA plans and operations France, series 1, Bureau of Area Operations, no. 1, Apr. 1945. 
Washington, he believed that the focus was not sufficiently on the quality of diet. He felt isolated both in the French Supply Council, composed in its majority by engineers, administrators, and industrialists, and struggled in its negotiations with the American military authorities: ' $[\mathrm{My}]$ work is very sad. It is in the Pentagon that we talk about calories...this program is naturally a very small piece of the whole program in the eyes of the Chief American Staff...What is unfortunate is that in an election year any question with the US is political. ${ }^{83}$

In Washington, the UNRRA's Health Division also valued the co-operation of the Fighting French Medical Authorities, notably General Sicé and his deputy Colonel Vignal, each of whom served on the Expert Commissions on Quarantine. ${ }^{84}$ This medical co-operation certainly drew upon a longer tradition of joint action. Equally, the UNRRA circulated expertise on scientific innovations such as DDT (dichloro-diphenyl-trichloroethane), which was used as an insecticide to control notably malaria and typhus. ${ }^{85}$ In London, a number of French planners also strove to encourage such technical co-operation in the field. ${ }^{86}$ The influence of these pro-UNRRA planners should, however, not be overestimated, as the official position of the FCNL did not change significantly in the following months. ${ }^{87}$

After the Allied Landings in Normandy on 6 June 1944, France became the theatre of intense and violent warfare to an even greater extent. The same month, the UNRRA planners deplored the absence of a coherent French policy. ${ }^{88}$ At the highest level of the administration, the UNRRA general director Lehman accused French authorities of favouring the American Red Cross over the UNRRA. ${ }^{89}$ In spite of these difficulties, on 15 July 1944 the UNRRA publicly recognized the FCNL as the Provisional Government of the French Republic, three months earlier than the government of the United States. $9^{\circ}$ On 28 August, at Dumbarton Oaks, the Allies also agreed to reserve a seat for France 'in due course' on the UN Security Council. However, these highly symbolic gestures did not translate into a significant revision of the French official position during the UNRRA's second council meeting, which convened in

${ }^{83} \mathrm{AN}, \mathrm{F} / 9 / 3116$, extrait d'une lettre d'André Mayer à Lt. Jean Mayer - resumé: situation de la France dans l'UNRRA, date du doc intercepté: 5 May 1944, date de l'interception: 26 May 1944; extrait d'une lettre d'André Mayer à Lt. Jean Mayer-resumé: commentaires sur l'activité de l'UNRRA - découverte scientifique, date du doc intercepté: 9 May 1944, date de l'interception: 26 May 1944 .

${ }^{8} 4$ UNA, UNRRA, ERO files, S-O ${ }_{52} 2-0012$, N. M. Goodman, 29 June 1944.

$8_{5}$ MAE, Alger, CFLN-GPRF, 691, activités américaines en Egypte, coopération de l'UNRRA aux travaux sanitaires, 26 June 1944 .

${ }^{86}$ UNA, UNRRA, ERO files, S-O523-0o12, R. Herbert to Mr Feonov, [June 1944?]; Sir Frederick Leith-Ross to Mr Lithgow Osborne, 22 June 1944.

87 MAE, Alger, CFLN-GPRF, 691, Alphand pour le Comité économique, no. 3255, 21 June 1944 .

${ }^{88}$ UNA, UNRRA, ERO files, S-O523-OO12, Col. Delahaye to Mr Osborne, 24 June 1944.

89 AFJME, AME $47 / 2 / 25$, lettre de Jean Monnet [report on his meeting with Lehman], Washington, 2 June 1944 .

9o 'UNRRA recognizes French Committee', New York Times, 16 July 1944. 
Montreal on 16 September 1944. Officially, the French wanted to present a delegation of a purely 'technical character' and neither Monnet nor Henri Hoppenot or Alphand participated.91 But this decision was in itself political, at a time of growing popular resentment towards the United States. The French were adamant that the UNRRA should not intervene on French soil. Monnet recommended supporting the American proposal to entrust the Displaced Persons Problem in Italy to the UNRRA and to endorse the Czech proposal to create a committee to study the problem of Austria. He insisted, though, that France had to be cautious before accepting the Soviet proposal to give priority to the countries that had suffered the most from enemy occupation and contributed most to the fight. For Monnet, this proposal was likely to be rejected by the British and the US, so France should only accept it if it applied to France. $9^{2}$ The French also insisted on the necessity to keep the UNRRA out of Indo-China, limiting its role to the questions of repatriation of displaced persons.

In October 1944, an UNRRA mission opened in Paris. The UNRRA personnel in the French capital were warned that 'if UNRRA was waiting for a formal written invitation from the French Government, UNRRA might well have to wait until the period of UNRRA's usefulness had passed'.93 In the autumn of 1944, de Gaulle, longing to break free from his country's state of forced dependence on his British and American allies, signed a treaty of alliance with the Soviet Union. No comparable alliance existed with either Britain or the United States. In addition to the worsening of the Franco-US relations, the lack of a coherent policy within the UNRRA also impeded the growth of harmonious relations between French and UNRRA staff. Planners in Washington, London, and Paris often had contradictory priorities and relations between the different UNRRA divisions did not always run smoothly. 94 This lack of co-ordination between different UNRRA branches was particularly striking in the planning of Displaced Persons (DP) operations.

DP divisions and committees had been established in Washington and London soon after the creation of the UNRRA, but communication between them was nugatory. The repatriation of French nationals held in Germany was a critical domestic challenge for the new republican elite seeking to establish its authority - and prove its legitimacy - to a nation left profoundly divided by the war. 95 Nearly a million French prisoners of war remained captive in Germany, while the German occupiers organized the deportations of 75,721

$9^{1}$ MAE, Alger, CFLN-GPRF, papiers Alphand, 1537, direction des affaires économiques, 15 Sept. 1944 .

$9^{2}$ AFJME, AME 45/4/61, Jean Monnet, 13 Sept. 1944.

93 UNA, UNRRA, S-0 $523-065^{\mathrm{O}-10}$, John Alexander to Mr Hoehler, 18 Oct. 1944.

94 UNA, UNRRA, S-O5 $5^{2} 3^{-0} 65^{\mathrm{O}-10}$, office of the UNRRA to ministère des PDR, 31 Oct. 1944 .

95 See for example Pieter Lagrou, The legacy of Nazi occupation: patriotic memory and national recovery in Western Europe, I945-1965 (Cambridge, 2000). 
persons considered as Jewish by French and German laws and 86,827 political deportees, convicted criminals, and hostages..$^{6}$ French repatriation authorities' relations with the UNRRA were contentious from the start and the UNRRA's provision soon fell short of French authorities' minimal expectations.97 Despite these tensions and early disappointments, though, French authorities decided in the summer of 1945 that the UNRRA should continue operating in the French zone of occupation in Germany.

At the centre of this decision were three key political imperatives: reinforcing French ties with the West, restoring France's influence in nascent international organizations, and facilitating French demographic policies in occupied Germany. Former Quai d'Orsay Political Director René Massigli was a pivotal figure in presenting the UNRRA's case. Dubious about the Soviet Union, Massigli valued the UNRRA as a means to strengthen cultural, economic, and political ties amongst the Western allies. $9^{8}$ A second, more intangible factor was that French Foreign Ministry staff were particularly sensitive over issues of prestige and the manner in which France was represented internationally. 99 Gratified that in August 1945 France had secured a seat on the UNRRA Central Committee, the Provisional Government subsequently ensured that the majority of the personnel working in the French zone were French nationals. In addition, Foreign Ministry experts shared Massigli's view that the UNRRA could provide 'diplomatic protection' for the recruitment of 'the most valuable' DPs to replenish a French population denuded by war. Since UNRRA Resolution 71 imposed on the organization an obligation to encourage the repatriation of displaced persons, however, the administration was not, in fact, well placed to provide this diplomatic protection.

\section{I}

By weaving together the story of French foreign policy and the creation of the UNRRA, this article demonstrates the importance of internationalism in French thinking about the post-war order. Two main approaches to the UNRRA can be identified during the period $1943^{-5}$. The first can be defined as a reluctant attitude towards this new international organization, with officials wanting to join the UNRRA only if France had the same status as the 'Four Policemen' in it. This position was based on a traditional conception of power and broader

\footnotetext{
${ }^{96}$ Fondation pour la mémoire de la deportation, Livre-Mémorial, www.fmd.asso.fr/web/ index.php?id_contenu=52 (last accessed 19 Apr. 2017).

97 Laure Humbert, 'French politics of relief and international aid: France, UNRRA and the rescue of European displaced persons in postwar Germany, 1945-1947', Journal of Contemporary History, $5^{1}$ (2016), pp. 6o6-34.

$9^{8}$ Raphaële Ulrich-Pier, René Massigli (I 888-1988): une vie de diplomate tome (2 vols., Paris, 2006), II, pp. 882-7, 937, 974; MAE, NUOI, 7, direction des conventions administratives, réunion à Londres du Conseil de l'UNRRA, 16 Aug. 1945.

99 Jean-Rémy Bezias, Georges Bidault et la politique étrangère de la France: Europe, États-Unis, Proche-Orient, 1944-1948 (Paris, 2006), pp. 165-77.
} 
denunciations of the US assumption of leadership in reshaping the post-war world. The second approach could be described as internationalist. Influenced by their experiences of the aftermath of the First World War, several officials and medical experts advocated international co-operation with the UNRRA. For these individuals, the UNRRA could bring precious knowledge, experience, and funds and help alleviate human suffering. Others, including René Cassin, also believed that co-operation with this new inter-governmental organization could improve 'the Franco-American atmosphere'. ${ }^{100}$ Finally, Monnet hoped that participating in the UNRRA could bolster French prestige and enhance France's security. Yet, many of these French proponents of international solutions were dismayed by American and British insensitivity to the cultural impact of occupation on continental Europe.

These French internationalists had little impact on the early development of post-war international relief. Their difficulties lay in part in the field of diplomatic relations and in part in the absence of clear and coherent French relief policies. After the invasion of North Africa, Washington stopped its official diplomatic relations with the Vichy regime in November 1942. Yet, during the UNRRA's first Council at Atlantic City, it became evident that while the postwar relief arena could be informed by expertise, it ultimately operated according to a different rationale than that of scientific and technical knowledge. French was not accepted as an official language in the UNRRA, despite French insistence that it constituted a 'traditional' language in sanitary and international conventions. France, which had contributed extensively to the Health Committee of the League of Nations in the interwar years, was not admitted to the UNRRA Central Committee until 1945. Disregarding its attempts at developing co-operation with Belgian, Dutch, and Luxemburgish authorities during the UNRRA's first Council, the FCNL was not even regarded as the 'natural' representative of 'small nations'. Although relief programmes were sometimes presented as non-political by the UNRRA official publicists, French policy elites - among them the very sceptical de Gaulle-were well aware that the provision of relief was in fact highly politicized. ${ }^{101}$

As France's place in the nascent UN system advanced, France's position within the UNRRA's administration improved and anxieties changed. In July 1944, the UNRRA recognized the French Committee as the Provisional Government. On 28 August 1944, at Dumbarton Oaks, the Allies agreed to reserve a seat for France 'in due course' on the UN Security Council. In October of the same year, the FCNL was recognized by its Allies as the undisputed Provisional Government of France. A month later, the possibility of French participation in the Allied occupation of Germany emerged at the European Consultative Council in London. Fears of American economic

${ }^{100} \mathrm{AN}$, papiers de Gaulle, 3/AG1/262, René Cassin sur une conversation confidentielle avec M. Leo Gerstenzang, Algiers, 3 Sept. 1943.

101 AN, papiers de Gaulle, 3/AG1/262, Jean Monnet à mon general, 10 Aug. 1943 . 
imperialism and concerns about food supplies and the repatriation of French nationals were superseded by anxieties about the potential role that the UNRRA and other UN agencies might play in the colonies. In February 1945, at Yalta, France was officially granted a zone in Germany. A few months later, France managed to obtain a seat on the UNRRA Central Committee. It also ensured that the majority of the UNRRA personnel were French in the French occupation zone in Germany's south-west. From being a 'recipient' of help, France became a member of the circles of 'provider' of help, although its financial contribution remained very limited.

This article has illuminated how studying the complex inter-relationship between French foreign policy and humanitarian relief efforts in the era of the Second World War can offer historians a framework through which to reconsider France's attempts to reassert its power globally. It has also demonstrated that the French case needs to be incorporated into this history of sometimes converging, often competing visions of 'international aid' in the mid-twentieth century. Indeed, in order to capture the complex and contingent nature of international collaboration in relief matters, we need to pay more attention to the innovative approach to relief developed by French expert planners in response to international pressures. These contacts and exchanges between French and Allied planners, albeit unsuccessful, revealed important potential and point to a political imperative that gave a new impetus to the post-war restructuring of French relief abroad. At the UN conference of San Francisco in 1945, it was clear for the French delegation that humanitarian organizations were platforms from which to bolster '[France's] cultural radiance' ${ }^{102}$

${ }^{102} \mathrm{AN}$, papiers Bidault, 457/AP/1, instructions du gouvernement à la délégation de San Francisco, Apr. 1945. 